\title{
Relation between Video Game Addiction and Interfamily Relationships on Primary School Students
}

\section{Selen Demirtas Zorbaz}

Hacettepe University

\author{
Ozlem Ulas \\ Hacettepe University \\ Seval Kizildag ${ }^{c}$ \\ Hacettepe University
}

\begin{abstract}
This study seeks to analyze whether or not the following three variables of "Discouraging Family Relations," "Supportive Family Relations," "Total Time Spent on the Computer," and "Grade Point Average (GPA)" predict elementary school students' video game addiction rates, and whether or not there exists a meaningful difference in students' video game addiction rates based on gender or on parents' levels of education. Being a descriptive survey model, the study group consists of 3964 th and 6 th grade primary school students. The following scales, prepared by the researchers, were used to gather data for this study: The Scale of Game Addiction for Children (SGAC), The Family Relationship Scale for Children (FRSC), and the Personal Information Form (PIF). The data gathered from the study were analyzed by using stepwise regression, one-way variance analysis, and independent sample t-test in SPSS. According to the findings of the study, while the variables "Discouraging Family Relations," "Time Spent on the Computer," and "GPA" predict 4th and 5th grade students' video game addiction rates in a meaningful way, the variable "Supportive Family Relations" does not. Moreover, it was seen that male students" video game addiction rates were higher than those of female students. The results of a oneway variance analysis show that there is no meaningful difference in students' video game addiction rates based on parents' levels of education. The findings were discussed under the light of the literature and suggestions and limitations discussed.
\end{abstract}

Keywords: Game addiction $\bullet$ Discouraging family relations $\bullet$ Supportive family relations $\bullet$ Students of elementary school $\bullet$ Computer

a Corresponding author

Selen Demirtas Zorbaz, Department of Educational Sciences, Faculty of Education, Hacettepe University, Ankara, Turkey

Research areas: Family relationships, counseling with children, child guidance, parenting skills, and school adjustment.

Email: selenpdragmail.com

b Ozlem Ulas, Department of Educational Sciences, Faculty of Education, Hacettepe University, Ankara, Turkey Email: ozlem_ulassahacettepe.edu.tr

c Seval Kizildag, Department of Educational Sciences, Faculty of Education, Hacettepe University, Ankara, Turkey Email: sevalpdragmail.com 
In the related literature, the situation which related to problematic playing computer games is described by different concepts. These concepts are game addiction, video addiction, internet addiction, pathological use of computer. In addition to this concepts, 'pathological technology use (PTU)' concept which is the term intended to include all of these is located within this wide range of concepts (Sim, Gentile, Bricolo, Serpelloni, \& Gulamoydeen, 2012).

Addiction is defined as an unpreventable desire and wish which occurs as a result of taking a substance in repeated doses and increasing amounts without aiming to eradicate the symptoms of an organic illness (Ziyalar, 1999). Media addiction, television addiction, cell phone addiction, computer, and internet addiction take place among technological addictions (Griffiths, 2000). The concepts of addiction and of behavioral addiction share a common quality in that one is "unable to control the action and continu[es] the behavior in spite of its negative results" (Henderson, 2001). Individuals addicted to the internet show such patterns as thinking excessively about the internet, a gradual increase in the level of pleasure derived from internet use, failure in attempts to decrease the harms of internet use, anger and disappointment as a result of undergoing these attempts, an increase in time spared using the internet, having problems in their social and occupational relations due to internet use, and preferring internet use to solving or coping with problems (Young, 1998).

A number of studies on technological addiction are seen when the literature is analyzed. According to the result of a study conducted in the USA (Morahan-Martin \& Schumacher, 2000) it was observed that individuals showed four or more of the symptoms of pathological internet use by $8.1 \%$ of individuals surveyed. While Gentile (2009) indicated that video games were played by $8.5 \%$ of individuals surveyed aged between 8 and 18, it was seen that $11.9 \%$ of the same age group suffered from computer addiction (Grüsser, Thalemann, \& Griffiths, 2007). In a study carried out in China, it was discovered that $10.32 \%$ of individuals surveyed played pathological video games (Peng \& Li, 2009 as cited in Sim et al., 2012). Additionally, it was observed that $1.5 \%$ of children surveyed aged between 13 and 16 suffer from game addiction in the Netherlands (Rooijl, Schoenmakers, Vermulst, Eijnden, \& Mheenl, 2010). Game addiction stands as a risk for children, regardless of age. In a study conducted involving students in nursery school and their families, it was detected that children played computer games for $0.53 \pm 0.53$ hours on average on week days and $1.62 \pm 1.56$ hours on weekends. Families reported that $48.8 \%$ of their children played computer games which contained violence one to four times in a week (Akçay \& Özcebe, 2012). Carbonell, Guardiola, Beranuy, and Belles (2009) stated in their study that there were many studies on addictions related to the internet, games, and cell phone use, respectively. Specifically, they concluded that communication and information technologies, such as internet, game, and cell phone addictions, were just as common as other behavioral addictions.

Colwell, Grady, and Rhaiti (1995) attribute the reasons of children's or teenagers' playing computer games to preferring computer games to friends, caring about virtual friendships, preferring actions, coping with the feeling of loneliness, and escaping from problems. In a study carried out by Jeong and Kim (2011), it is seen that there is a negative meaningful relation between game addiction and children's social self-efficiency and their participation in social activities with their parents. At the same time, they found a negative meaningful relation between parents' attitudes toward games and children's game addiction. In another study on video game addiction (Weinstein, 2010), articles published in 2000 and 2009 were studied with the goal to ascertain the reasons behind and the results of video game addiction. Accordingly, psycho-social mechanisms underlying video game addiction were generally revolved around coping with stress, emotional reactions, desensitization, and rewards. In the long term, computer games caused changes in individuals' reward mechanism in a way similar to the effects of drug addiction. Similarly, in another study conducted on video game addiction (Demirtaş-Madran \& Çakılcı, 2014), it was found that there existed a positive meaningful relation between aggressiveness and game addiction.

It is known that video game addiction influences children's academic success in a negative way. In the related literature, it is observed that both children's and teenagers' game addiction has negative meaningful relations with academic success and family function (Chiu, Lee, \& Huang, 2004), and that one's tendency to fall into game addiction is in negative meaningful relations with school performance (Skoric, Ching Teo, \& Neo, 2009) and school efficiency (Hastings et al., 2009) Furthermore, it is supported by separate studies which describe a positive meaningful relation 
between the time spent on playing games (Hastings et al., 2009), lower school success, school truancy (Rehbein, Psych, Kleimann, Mediasci, \& Möble, 2010) and game addiction.

In those studies analyzing the relation between game addiction and gender, it was observed that playing computer games was equally popular among men and women, that men allowed more time for playing computer games than did women, and that there was a negative meaningful relation between women's levels of playing computer games and attaining satisfaction from them (Colwell et al., 1995). Furthermore, it was also found in a number of studies in the literature that females experience game addiction at a lower rate than do males (Akçay \& Özcebe, 2012; Erboy, 2010; Griffiths \& Hunt, 1995; Güllü, Arslan, Dündar, \& Murathan, 2012; Horzum, 2011; Rehbein et al., 2010; Şahin \& Tuğrul, 2012). In addition, there are also studies present in the literature stating that there is no meaningful difference based on gender (Bilge, 2012).

Family is an important factor in a child's social, emotional, and cognitive development, among other areas. Yavuzer (2004) states that the formation of a child's personality, the shaping of his/her character, and the development of his/her self-respect are based on parents' personality type, or in other words family structure, since it is, by and large, their main identification model. In this regard, it is thought that family will be a both, risk factor and have a protective function in children's game addiction. Even though studies analyzing game addiction and family relations are few in number, studies on other sorts of addiction and family relations are more commonplace.

Studies show there to be a meaningful relation between family relations, drug addiction (Johnson, McBride, Hopkins, \& Pepper, 2014), and internet addiction (Liu \& Kuo, 2007; Mesch, 2003; Yen, Yen, Chen, Chen, \& Ko, 2007). In a study analyzing family's attitudes toward internet and internet addiction, it was found that families' negligent attitudes toward the internet itself played an important role in their children developing an addiction to the internet (Ayas \& Horzum, 2013).

It is thought that coupled with other family relations, parents' level of education can be regarded as one of the factors effective on children developing video game addiction. As a result of a study conducted by Şahin and Tuğrul (2012), it was found that as the level of education of one's mother increased, so did the rate of addiction to video games increase in the child compared to children whose mother's educational level was relatively lower. It was also discovered in the same study that male students had a higher level of computer game addiction as compared to female students and that those who owned a computer at home had a higher level of computer game addiction when compared to those who did not own a computer at home. In the same study, a meaningful difference concerning computer game addiction in terms of the educational level or social class of one's fathers educational was not found. Erboy (2010), in his study, showed that children's levels of game addiction changed according to the level of education of one's mother.

Studies on game addiction and their negative effects on children's emotional, cognitive, and social development are limited in number in Turkey. Today, technology severely influenced the life to support the healthy development of children's, preventing or lessening the effects of behavioral addictions such as game addiction that makes child lonely, blunts his cognitive skills, hardens his social adaptation is one of the topics which should be emphasized strongly both in the family and the general population. In this regard, in an effort to contribute to the existing research in this field in Turkish literature, the current study aimed to reveal which variables might affect $4^{\text {th }}$ and $5^{\text {th }}$ grade students' rates of game addiction. In this context, the current study sought answered to the following research questions.

1. Do the following variables of discouraging family relations, supportive family relations, total time spent on computer, and GPA predict $4^{\text {th }}$ and $5^{\text {th }}$ grade students' rates of video game addiction in a meaningful way?

2. What is the power of predictive variables together in predicting $4^{\text {th }}$ and $5^{\text {th }}$ grade students' rates of video game addiction?

3. Is there a meaningful difference in $4^{\text {th }}$ and $5^{\text {th }}$ grade students' rates of video game addiction according to gender?

4. Is there a meaningful difference in $4^{\text {th }}$ and $5^{\text {th }}$ grade students' rates of video game addiction according to the level of education of one's mother?

5. Is there a meaningful difference in $4^{\text {th }}$ and $5^{\text {th }}$ grade students' rates of game addiction according to the level of education of one's father? 


\section{Method}

This study has been modeled in the form of a descriptive survey with the appropriate technique of sampling being used in it. Appropriate sampling is a common sampling technique which is used especially in studies focusing on humanitarian aid. It is preferred for its being both practical and economical (Monette, Sulivan, \& Dejong, 1990 as cited in Özen \& Gül, 2007).

\section{Study Group}

The study group consisted of $3964^{\text {th }}$ and $5^{\text {th }}$ grade students from three public primary schools under the direction of Turkey's Ministry of National Education. The schools used in the study were selected randomly in the city of Ankara during the 2012-2013 academic year. The students from all of the schools have, in general, a middle socioeconomic level. During the time of the study, 97 (24.5\%) of the total 396 students were studying in fourth grade and $295(74.5 \%)$ of them were studying in fifth grade, with 200 (50.5\%) of them being girls and 196 (49.6\%) of them being boys. Four students did not state their grade level.

\section{Means of Data Collection}

Scale of Game Addiction for Children (SGAC): This scale was developed by Horzum, Ayas, and Çakır-Balta (2008) in order to measure video game addiction levels in third, fourth and fifth grade students. The scale consists of 21 items and four factors; namely, (1) not giving up playing computer games and being disturbed when prevented from playing, (2) seeing computer games in one's dreams and associating then with real life, (3) delaying responsibilities due to playing computer games, and (4) preferring computer games to other activities. A high score obtained from the scale shows that children's levels of game addiction are high. The Cronbach Alpha reliability coefficient of the scale was found to be .85 (Horzum et al., 2008). In the current study however, the Cronbach Alpha reliability coefficient of the scale was found to be .83 .

The Family Relationship Scale for Children (FRSC): This scale was developed by DemirtaşZorbaz and Korkut-Owen (2013) in order to measure the family perceptions of fourth and fifth grade students. The FRSC consists of two dimensions and 20 items. The Cronbach Alpha reliability coefficients of the scale were found to be .82 and .84 for the sub-dimension of Discouraging
Family Relations and to be .76 and .78 for the sub-dimension of Supportive Family Relations. A high score obtained in the sub-dimension of Discouraging Family Relations indicates that children have a negative perception of their interfamily (i.e. a discouraging family relation) whereas a high score in the sub-dimension of Supportive Family Relations indicates that children perceive their interfamily relations as supportive (Demirtaş-Zorbaz \& Korkut-Owen, 2013). In this study, the Cronbach Alpha reliability coefficient was found to be .72 for discouraging family relations and .78 for supportive family relations.

Personal Information Form (PIF): In this study, the Personal Information Form, which was developed by researchers and which consists of five items, was used in order to ascertain students' gender, socio-economic class levels, parents' levels of education, GPA, and time spent on a computer each day.

\section{Process}

The data of this study was collected from three public primary schools under the direction of Turkey's Ministry of National Education in the city of Ankara during the 2012-2013 academic year by researchers. After obtaining the required permission, researchers visited students' classrooms together with the classroom teacher and instructed them on how to complete the study forms. The students were encouraged to join the study and tests were given to willing students. This process was completed in 20 minutes.

In the study, while a stepwise regression analysis was used in order to define the predictors of game addiction, $\mathrm{t}$-test analysis techniques for independent samples were taken for analysis in SPSS 15.00 so as to determine whether or not children's rates of game addiction changed according to gender. Just as the Pearson correlation coefficient was calculated in order to determine the relation between students' GPA and game addiction, so were oneway variance analysis techniques benefited from in order to determine whether or not students' rates of game addiction changed according to their parents' education level.

\section{Findings}

A stepwise regression analysis was performed in order to determine which variables were effective in predicting game addiction. Whether or not there 
was a problem of multi relatedness from regression assumptions was determined by analyzing both the correlations between variants and the values of variance inflation (VVI).

When correlations between variables were examined, neither a correlation coefficient above .80 nor a VVI value above five was found. After examining the dependent variable' coefficient of skewness, the distribution was found not to be skewed. Furthermore, although the distribution of the kurtosis coefficient for the dependent variable was slight, the results of the Kolmogorov-Smirnov test show that the dependent variable was distributed normally. The correlations between dependent and independent variables are given in Table 1.

\section{Table 1}

Correlations Between Dependent and Independent Variables (Test Scores)

\begin{tabular}{lccccc}
\hline & $\mathbf{1}$ & $\mathbf{2}$ & $\mathbf{3}$ & $\mathbf{4}$ & $\mathbf{5}$ \\
\hline 1.SumGA & 1,000 & & & & \\
2.Comp. Hour & .262 & 1,000 & & & \\
3.GPA & -.271 & .004 & 1,000 & & \\
$\begin{array}{l}\text { 4.Supportive family } \\
\text { relationship }\end{array}$ & -.208 & -.059 & .201 & 1,000 & \\
5. Discouraging & .441 & .108 & -.185 & -.406 & 1,000 \\
family relations & & & & & \\
\hline $\begin{array}{l}\text { Mean } \\
\text { Standard Deviation }\end{array}$ & 11,81 & 1,11 & 14,90 & 3,40 & 3,34 \\
Skewness & 0,97 & 2,96 & $-2,12$ & $-1,05$ & 1,36 \\
Kurtosis & 1,92 & 14,59 & 8,10 & 0,62 & 2,92 \\
\hline
\end{tabular}

The regression co-efficients were analyzed in order to determine whether independent variables' ability to predict dependent variables was statistically important in the model. In Table 2, the results of the regression analysis for the variables that affected students' game addiction levels are presented. The selection of the best model for predicting game addiction was researched using a stepwise regression analysis from which three different models of regression were obtained. The results of the stepwise regression analysis performed on the data for those variables observed to be effective predictors of game addiction are given in Table-2, explained below.

Table 2 reveals the stepwise regression analysis for predicting the game addiction levels of the 4th and 5th grade students participating in the study, completed in three stages. As can be seen in Table 2, since "Supportive Family Relationships" did not predict students' level of game addiction, it has not been included in the analysis. However, the other three variables were included in the stepwise regression analysis.

Analyzing both standardized regression coefficients (Beta coefficient) and dual and partial correlations, while a positive meaningful relation is observed between the variables "Discouraging Family Relations" and "Spending Time on the Computer" and game addiction, negative meaningful relations were observed between the variable "GPA" and

\section{Table 2}

Stepwise Regression Analysis Results for the Variables of Discouraging family relations, Spending Time on the Computer, and GPA

\begin{tabular}{|c|c|c|c|c|c|c|c|}
\hline Model & \multicolumn{2}{|c|}{$\begin{array}{c}\text { Standardized } \\
\text { Beta Co-efficient }\end{array}$} & $\beta$ & $t$ & $\mathbf{R}$ & $\mathbf{R}^{2}$ & $\mathrm{R}^{2}$ change \\
\hline \multirow{3}{*}{$\begin{array}{l}\text { 1. (Constant) } \\
\text { Discouraging family relations }\end{array}$} & 20.921 & 2.484 & & $8.424^{\star * *}$ & & & \\
\hline & & & & & .441 & .174 & .174 \\
\hline & 1.518 & .170 & .441 & $8.927^{\star * *}$ & & & \\
\hline \multirow{3}{*}{$\begin{array}{l}\text { 2. (Constant) } \\
\text { Discouraging family relations Spending Time } \\
\text { on the Computer }\end{array}$} & 19.480 & 2.436 & & $7.997^{* * *}$ & \multirow{3}{*}{$.490^{\mathrm{b}}$} & \multirow{3}{*}{.240} & \multirow{3}{*}{.046} \\
\hline & 1.487 & .166 & .417 & $8.644^{* * *}$ & & & \\
\hline & 2.345 & .522 & .217 & $4.491^{\star * *}$ & & & \\
\hline \multirow{4}{*}{$\begin{array}{l}\text { 3. (Constant) } \\
\text { Discouraging family relations Spending Time } \\
\text { on the Computer } \\
\text { GPA }\end{array}$} & 34.673 & 4.301 & & $8.062^{\star * *}$ & \multirow{4}{*}{$.529^{c}$} & \multirow{4}{*}{.280} & \multirow{4}{*}{.039} \\
\hline & 1.307 & .165 & .379 & $7.918^{\star * *}$ & & & \\
\hline & 2.398 & .509 & .222 & $4.708^{\star * *}$ & & & \\
\hline & -.160 & .038 & -.202 & $-4.238^{\star * *}$ & & & \\
\hline
\end{tabular}

Dependent variable: Game addiction

${ }^{*} p<.05,{ }^{* *} p<.01,{ }^{* * *} p<.001$

a. predictors (constant), Discouraging family relations

b. predictors (constant), Discouraging family relations Spending Time on the Computer

c. predictors (constant), Discouraging family relations Spending Time on the Computer, GPA 
game addiction. It is seen that the variables "Discouraging Family Relations," "Spending Time on the Computer," and "GPA" together explain $28 \%$ of the total variance in $4^{\text {th }}$ and $5^{\text {th }}$ grade students' video game addiction rates $\left(\mathrm{R}=0.529, \mathrm{R}^{2}=0.280\right)$.

The standardized regression coefficient (Beta) of the variable "Discouraging Family Relations" studied in the first step of the stepwise regression analysis was 0.441 . It is seen that the variable "Discouraging Family Relations," on its own, explains about 19\% of the total variance in students' game addiction rates $\left(\mathrm{R}=0.441, \mathrm{R}^{2}=0.194\right)$. The dual correlation between the variable of "Discouraging Family Relations" and game addiction rates was found to be positive and meaningful $(r=0.441)$.

In the second step of the stepwise regression analysis, the variable "Spending Time on the Computer" was entered into the model in addition to the variable "Discouraging Family Relations". Adding a contribution of $4.5 \%$ to the explanation of total variance, the variant "Spending Time on the Computer" increased the total explained variance in video game addiction rates to $24 \%\left(\mathrm{R}^{2}\right.$ change $\left.=0.046, \mathrm{R}=0.490, \mathrm{R}^{2}=0.240\right)$. Provided that other variants stay stable, the Beta coefficient of the variable "Discouraging Family Relations" was found to be 0.417 ; the Beta coefficient of the variable "Spending Time on the Computer" was found to be -0.217 . The $t$ values of both Beta coefficients are at a meaningful level. The dual correlation between the variable "Spending Time on the Computer" and video game addiction rates was found to be positive and meaningful $(r=0.262)$. It was seen that the variable "Spending Time on the Computer" was very effective in explaining game addiction rates when combined with the variable "Discouraging Family Relations."

In the third step of the stepwise regression analysis, the variant "GPA" was added to the model in addition to the variables "Discouraging Family Relations" and "Spending Time on the Computer." Adding a contribution of $3.9 \%$ to the explanation of total variance, the variant GPA increased the total explained variance in video game addiction rates to $28 \%$ ( $\mathrm{R}^{2}$ change $=0.039, \mathrm{R}=0.529, \mathrm{R}^{2}=0.280$ ). Provided that the other variables remain stable, the Beta coefficient of the variable "Discouraging Family Relations" was found to be 0.379 , the Beta coefficient of the variable "Spending Time on the Computer" was found to be 0.222 , and the Beta coefficient of the variable "GPA" was found to be -0.202 . The $t$ values of these three Beta coefficients were found meaningful. The dual correlation between the variable "GPA" and video game addiction rates was found to be negative and meaningful $(r=-0.271)$.

During the fourth step of stepwise regression analysis, it was observed while analyzing the variables entered into the model that the Beta coefficient of the variable "Discouraging Family Relations" was the highest (0.379) whereas that of the variable "GPA" was the lowest (-0.202). While analyzing the variables' regression coefficients as well as their $t$ and $\mathrm{R}^{2}$ values, it is seen that $4^{\text {th }}$ and $5^{\text {th }}$ grade students' video game addiction rates may be predicted meaningfully by the variable "Discouraging Family Relations," with the highest contribution; "Spending Time on the Computer," with the second highest contribution; and "GPA" with the least contribution of the three. It is understood that the variable "Supportive Family Relations" has no meaningful predictive effect on $4^{\text {th }}$ and $5^{\text {th }}$ grade students' video game addiction rates.

As a result, the variables of "Discouraging Family Relations," "Spending Time on the Computer," and "GPA" predict game addiction at a meaningful level whereas "Supportive Family Relations" does not. The variables of "Discouraging Family Relations," "Spending Time on the Computer," and GPA together predict $28 \%$ of game addiction. It was found that $4^{\text {th }}$ and $5^{\text {th }}$ grade students' game addiction levels were predicted mostly by "Discouraging Family Relations," followed by "Spending Time on the Computer," and finally by "GPA."

A $t$-test was applied for independent groups in order to determine whether or not students' video game addiction rates changed according to gender, in which was found a statistically meaningful difference between the video game addiction rates of female students' and those of male students $(t(394)=-5.223$, $p<0,001)$. According to the results of the t-test for applied independent samples, it is observed that male students' video game addiction rates $(\bar{x}=46.32$ $\mathrm{s}=11.49, \mathrm{n}=196)$ are higher than those of female students $(\bar{x}=40.32, \mathrm{~s}=11.37, \mathrm{n}=200)$.

According to variance results, it may be understood that none of the differences between the average scores of the video game addiction rates of students whose mothers have different education levels is meaningful since the $\mathrm{F}$ statistic in the model is not meaningful $\left(\mathrm{F}_{3 ; 366}=1.81 ; p>0.05\right)$. In the current study, it was concluded that the differences between the averages of the game addiction scores for students with mothers of different education levels were not statistically meaningful. In other words, differences in the education levels of students' mothers do not 
constitute an important difference in students' video game addiction rates. After analyzing the Eta square value, the fact that it has a very low effect, that being $\mathrm{h}^{2}=0.01$, supports the notion that the education level of one's mother has no important effect on students' video game addiction scores.

At the same time, since the F statistic in the model is not meaningful $\left(\mathrm{F}_{3 ; 371)}=1.62 ; p>0.05\right)$, it may be understood that the difference between the average video game addiction scores of students whose fathers have different education levels is not meaningful. In the current study, the researchers concluded that the differences observed in the game addiction scores of students whose fathers have different levels of education were not statistically meaningful. In other words, fathers' education level is not an important factor in explaining the differences in students' video game addiction rates. After analyzing the Eta square value, the fact that it has a very low effect, that being $\mathrm{h}^{2}$ $=0.01$, supports the notion that the education level of one's father has no important effect on students' video game addiction scores.

\section{Discussion}

The research findings show that the variable "Discouraging Family Relations" ranks first among the predictors of $4^{\text {th }}$ and $5^{\text {th }}$ grade students' video game addiction rates. It was discovered that family relations are important in explaining primary school students' video game addiction rates. The findings of the current study are in line with the findings of the study conducted by Chiu et al. (2004). Furthermore, Jeong and Kim (2011) state that the amount and quality of social time spent with one's parents has effect on individuals' video game addiction. Regarding the literature, even though only a few number of studies on video game addiction and family relations have been conducted, there do exist studies which showing there to be a meaningful relation between internet addiction and family relations (Liu \& Kuo, 2007; Mesch, 2003; Yen et al., 2007).

Since one's family plays such an important role in a child's individual and social development, a lack of effective communication within the family, the fact that family roles are neither clear nor apparent, and that absence of emotional closeness in one's family all are factors which act to turn one's family into a risk factor. Given the age range of the study group in the current study, it may be said that family relations have a serious influence on the related age group. In this regard, it can be said that particular preventive guidance studies on video game addiction should be conducted while organizing psychological consultation and guidance activities in primary education. While preparing preventive programs for a child or family, school counselors should consider the notion that family relations constitute a risk factor so as to structure their programs accordingly.

The research findings have shown that the variable "Time Spent on the Computer" ranks second among the predictors of $4^{\text {th }}$ and $5^{\text {th }}$ grade students' video game addiction rates. This finding is similar to that of Hastings et al. (2009) and that of Bilge (2012). One of the symptoms of video game addiction is that an individual spends more time than necessary on the computer. While analyzing the research findings of the current study, it is observed that game addiction increases as the amount of time spent on the computer increases. In order to prevent students from spending time on computer unnecessarily and, contrarily, to enable them to engage in activities that will support their cognitive, social, and/or affective development, teachers and families can be presented service with psycho-educational studies by school counselors so as to help them to diversify both in-school and extraschool activities.

The variable "GPA" ranked third and last among the predictors of $4^{\text {th }}$ and $5^{\text {th }}$ grade students' video game addiction rates. This finding is similar to those of other students within the literature (Chiu et al., 2004; Hastings et al., 2009; Rehbein et al., 2010; Skoric et al., 2009). Both in this study's and in the findings of related studies, it is observed that video game addiction influences students' academic performance negatively.

While analyzing the dual correlation between GPA and video game addiction rates, a negative meaningful relation between the two variable in question becomes manifest. Addiction affects an individual's ability to function effectively in different areas of his/her life Addiction affects an individual's ability to function effectively in different areas of his/her life. When considering to primary school students, it can be seen that they spend most of their time at the school area. That's why school is one of the important places in which $4^{\text {th }}$ and $5^{\text {th }}$ grade students can actively participate. It is an expected result that video game addiction affects not only one's relationship with his/her family, but also his/her relationship with the school environment and levels of academic success.

It is possible that a dual relation exists between GPA and video game addiction rates. Since individuals suffering from video game addiction spend an 
excessive amount of much time on computers and are not inclined to meet their needs, except for physical ones, they may not show the necessary care and attention required to achieve academic success. For example, they may not fulfill their academic responsibilities, such as completing homework, following their lessons regularly, and studying for their exams and, which as a result, may cause their success at school to decrease. In spite of this, a child who is unsuccessful at school may try to satisfy his need to feel as a success through videos games. For this reason, future researchers should take into consideration that students with lower GPA levels are more likely to become video game addicts and that video game addicts' levels of academic success may continue to decrease over time when conducting their research.

In the current study, an answer was sought for the question “Are $4^{\text {th }}$ and $5^{\text {th }}$ grade students' video game addiction rates meaningfully different according to gender?" Based on the findings of this study, it is seen that male students' video game addiction rates are higher than those of female students. This finding is similar to those of other studies within the literature (Bilge, 2012; Colwell et al., 1995; Erboy, 2010; Griffiths \& Hunt, 1995; Horzum, 2011; Rehbein et al., 2010; Şahin \& Tuğrul, 2012). Especially when considering the cultural stereotypes relating to gender roles it can be said that technological activities related to gender roles determined by society may be causing that male students more often to prefer technological activities. For this reason, it is important that "gender differences" be considered in future studies so as to prevent video game addiction while arranging the content of classroom activities and psychoeducational programs.

An answer was sought for the question "Are $4^{\text {th }}$ and $5^{\text {th }}$ grade video game addiction rates meaningfully different according to one's parents' education level? The results of the research show that there is no meaningful difference in $4^{\text {th }}$ and $5^{\text {th }}$ grade students video game addiction rates based on parents' level of education. Although in the studies made by Erboy (2010) and Şahin and Tuğrul (2012), a difference in primary school students' video game addiction rates based on the education level of one's mother was observed, Şahin and Tuğrul stated that there was no difference according to the education level of one's father.

In conclusion, evaluating the attained findings, it is seen that the concept of family is important in preventing video game addiction. Both "Time Spent on the Computer" and "GPA" are important variables in predicting video game addiction. In addition, a meaningful difference in video game addiction rates was found based on gender.

Today, as activities requiring the use of technology increase daily, so does the risk of video game addiction. It may be proposed that in order to prevent game addiction, establishing intervention centers and making intervention plans will increase in importance. It is an important condition that those experts who are to work in such intervention centers have either undergone counselor education or studied the education of psychology. Children's interest in technology and computers should be directed toward areas such as web site designing and information transfer through the internet so as to be able to influence their cognitive aspect directly rather than to such activities as playing computer games since they carry with them the risk of developing a technological addiction. Considering that children stay at home more in their free time as a result of playgrounds' becoming more sparse due to urbanization, creating safe, outdoor playgrounds and directing children to such activities in order to allow them to spend their free time effectively may necessitate inter-institutional cooperation in future studies seeking means to prevent children from falling into video game addiction.

\section{Suggestions for Future Research}

The variables "Discouraging Family Relations," "Spending Time on the Computer," and "GPA" explain $28 \%$ of the total variance in students' rates of video game addiction. In this regard, in addition to these variants, other variables, such as friends, school, and teachers that find themselves in a student's ecological system, may also affect students' video game addition rates. As such, it is recommended that the effects of such variables be researched.

Looking at other studies on the prevalence of video game addiction, it is observed that individuals between the ages of 8 and 18 have the highest risk of falling into video game addiction. Regarding this situation, it can be advised that future studies on video game addiction be made both longitudinally and in a cross-sectional way, including in them the period of adolescence.

\section{Limitations of Research}

This study was carried out on students of three schools in the central provinces of Ankara, Turkey. Since the findings of this study are generalizable only as long as they resemble other groups, the sample group itself is the most apparent limitation of this study. 


\section{References}

Akçay, D., \& Özcebe, H. (2012). Okul öncesi eğitim alan çocukların ve ailelerinin bilgisayar oyunu oynama alışkanlıklarının değerlendirilmesi. Çocuk Dergisi 12(2), 66-71. doi:10.5222/j.child.2012.066

Ayas, T., \& Horzum, M. B. (2013). İlköğretim öğrencilerinin internet bağımlılığı ve aile internet tutumu. Türk Psikolojik Danışma ve Rehberlik Dergisi, 4(39), 46-57.

Bilge, F. (2012). Bir grup ilköğretim öğrencisinde bilgisayara yönelik bağımlılık eğilimlerinin belirlenmesi. Hacettepe Üniversitesi Eğitim Fakültesi Dergisi, 43, 96-105.

Carbonell, X., Guardiola, E., Beranuy, M., \& Belles, A. (2009). A bibliometric analysis of the scientific literature on internet, video games, and cell phone addiction. Journal of the Medical Library Association, 97(2), 102-107. doi: 10.3163/1536-5050.97.2.006

Chiu, S., Lee, J. Z., \& Huang, D. H. (2004). Video game addiction in children and teenagers in Taiwan. CyberPsycology \& Behavior, 7(5), 571-581. doi: 10.1089/1094931042403127

Colwell, J., Grady, C., \& Rhaiti, S. (1995). Computer games, self-esteem and needs in adolescents. Journal of Community \&Applied Social Psychology, 5, 195-206. doi: 10.1002/casp.2450050308

Demirtaş-Madran, H. A., \& Çakılcı, E. (2014). The relationship between aggression and online video game addiction: A study on massively multiplayer online video game players. Anadolu Psikiyatri Dergisi, 15(2), 99-107.

Demirtaș-Zorbaz, S., \& Korkut-Owen, F. (2013). Cocuklar için aile ilişkileri ölçeğinin geliştirilmesi. Türk Psikolojik Danışma ve Rehberlik Dergisi, 4(39), 58-67.

Erboy, E. (2010). İlköğretim dördüncü ve beșinci sınıf öğrencilerinin bilgisayar oyun bağımlılı̆̆ına etki eden faktörler (Master's thesis, Aydın Menderes University, Aydın, Turkey). https://tez2.yok.gov.tr/ adresinden edinilmiștir.

Gentile, D. (2009). Pathological video-game use among youth ages 8 to 18: A national study. Psychological Science, 20(5), 594-602. doi: 10.1111/j.1467-9280.2009.02340.x

Griffiths, M. D., \& Hunt, N. (1995). Computer game playing in adolescence: Prevalence and demographic indicators. Journal of Community \& Applied Social Psychology, 5, 189193. doi: $10.1002 /$ casp. 2450050307

Griffiths, M. D. (2000). Internet addiction- time to be taken seriously? Addiction Research, 8(5), 413-418.

Grüsser, S. M., Thalemann, R., \& Griffiths, M. D. (2007). Excessive computer game playing: Evidence for addiction and aggression? Cyberpsychology and Behavior, 10(2), 290-292.

Güllü, M., Arslan, C., Dündar A., \& Murathan, F. (2012). İlköğretim öğrencilerinin bilgisayar oyun bağımlılıklarının incelenmesi. Adiyaman Üniversitesi Sosyal Bilimler Enstitüsü Dergisi, 5(9) 89-100.

Hastings, E. C., Karas, T. L., Winsler, A., Way, E., Madigan, A., \& Tyler, S. (2009). Young children's video/computer game use: Relations with school performance and behavior. Issues in Mental Health Nursing, 30, 638-649. doi: 10.1080/01612840903050414

Henderson, E. C. (2001). Understanding addiction. Jackson, MI: University Press of Mississippi.

Horzum, M. B. (2011). İlköğretim öğrencilerinin bilgisayar oyunu bağımlılık düzeylerinin çeşitli değişkenlere göre incelenmesi. Eğitim ve Bilim, 36(159), 56-68.
Horzum, M. B., Ayas, T., \& Çakır-Balta, Ö. (2008). Çocuklar için bilgisayar oyun bağımlılığı ölçeği. Türk Psikolojik Danışma ve Rehberlik Dergisi, 3(30), 76-88.

Jeong, E. J., \& Kim, D. H. (2011). Social activities, self-efficacy, game attitudes, and game addiction. Cyberpsychology, Behavior and Social Networking, 14(4), 213-221. doi: 10.1089/cyber.2009.0289

Johnson, B., McBride, D., Hopkins G., \& Pepper, S. (2014). An examination of parent-child relationships and teen substance use: a brief report. Journal of Child \& Adolescent Substance Abuse, 23, 210-216. doi: 10.1080/1067828X.2013.786926

Liu, C., \& Kuo, F. A. (2007). A study of internet addiction through the lens of the interpersonal theory. CyberPsychology and Behavior, 10, 799-804. doi: 10.1089/ cpb.2007.9951

Mesch, G. S. (2003). The family and the internet: the Israeli case. Social Science Quarterly, 84, 1038-1050. doi: 10.1046/j.0038-4941.2003.08404016.x

Morahan-Martin, J., \& Schumacher, P. (2000). Incidence and correlates of pathological internet use among college students. Computers in Human Behavior, 16(1), 13-29.

Özen, Y., \& Gül, A. (2007). Sosyal ve eğitim bilimleri araștırmalarında evren-örneklem sorunu. Kazım Karabekir Eğitim Fakültesi Dergisi, 15, 394-422.

Rehbein, F., Psych, G., Kleimann, M., Mediasci, G., \& Möble, T. (2010). Prevalence and risk factors of video game dependency in adolescence: results of a German nationwide survey. CyberPsycology \& Behavior and Social Networking, 13(3), 269-277. doi: 10.1089=cyber.2009.0227

Rooijl, A. J., Schoenmakers, T. M., Vermulst, A. A., Eijnden, R. J. J. M., \& Mheenl, D. (2010). Online video game addiction: Identification of addicted adolescent gamers. Addiction Research Report, 106, 205-212. doi:10.1111/ j.1360-0443.2010.03104.x

Sim, T., Gentile, D. A., Bricolo, F., Serpelloni, G., \& Gulamoydeen, F. (2012). A conceptual review of research on the pathological use of computers, video games, and the Internet. International Journal of Mental Health Addiction, 10, 748-769. doi: 10.1007/s11469-011-9369-7

Skoric, M. M., Ching Teo, L. L., \& Neo, R. L. (2009). Children and video games: Addiction, engagement and scholastic achievement. CyberPsycology \& Behavior, 12(5), 565-572. doi: $10.1089=$ cpb. 2009.0079

Şahin, C., \& Tuğrul, V. M. (2012). İlköğretim öğrencilerinin bilgisayar oyunu bağımlılık düzeylerinin incelenmesi. Journal of World of Turks, 4(3), 115-130. doi: 10.1111/j.1467-9280.2009.02340.x

Weinstein, A. M. (2010). Computer and video game addiction-a comparison between game users and nongame users. The American Journal of Drug and Alcohol Abuse, 36, 268-276. doi: 10.3109/00952990.2010.491879

Yavuzer, H. (2004). Ana - baba ve çocuk: Ailede çocuk eğitimi. İstanbul: Remzi Yayıncılık.

Yen J., Yen, C., Chen, C., Chen, S., \& Ko, C. (2007). Family factors of internet addiction and substance use experience in Taiwanese adolescents. CyberPsychology and Behavior, 10, 323-329. doi: 10.1089/cpb.2006.9948

Young, K. S. (1998). Internet addiction: The emergence of a new clinical disorder. Cyberpsychol Behaviour, 11, 237-244. doi: $10.1089 / \mathrm{cpb} .1998 .1 .237$

Ziyalar, A. (1999). Sosyal psikiyatri. İstanbul: Yüce Yayıncilik. 